\title{
Kadınların Refahını Artırmaya Yönelik Çalışan Meslek Elemanlarının Mesleki Yeterlilik ve İş Doyumuna Yönelik Bir Araştırma
}

\section{An Analysis of the Professional Competence and Job Satisfaction of Members of Professions Working to Enhance Women's Welfare}

\author{
İpek Beyza ALTIPARMAK* \\ Gülçin CEBECIOOĞLU ** \\ Yasemin ERTAN KOÇAK ***
}

Öz: Kadınların çalışma, eğitim ve sosyal hayatlarında çeşitli problemler yaşadıkları bilinmektedir. Bu problemleri çözmeye ve kadınların refahını artırmaya yönelik pek çok çalışma yapılmakta ve hatta konu ile ilgili olarak çeşitli istihdam alanları oluşturulmaktadır. Kadın refahını artırmaya yönelik yapılan bu çalışmaların etkinliği ve verimliliği üzerinde o alanda çalışan meslek elemanlarının rolü oldukça fazladır. $\mathrm{Bu}$ düşünceden hareketle yapılan araştırmada kadın refahını artırmaya yönelik çalışan meslek elemanlarının mesleki yeterlilik ve iş doyumlarının belirlenmesi amaçlanmaktadır. Bu noktada nitel araştırma tekniği özelliği taşıyan çalışma 65 meslek elemanıyla gerçekleştirilmiştir. Araştırma kapsamında öncelikli olarak katılımcıların demografik bilgileri alınmış, sonrasında aldıkları eğitim, mesleğe başlamadan önceki beklentileri, bu beklentilerinin karşılanıp karşılanmadığı, üniversiteden aldıkları eğitimlerin mesleki anlamda yeterli olup olmadığı, çalıştıları kurumda oryantasyon eğitimi alıp almadıkları gibi bilgiler sorgulanmıştır. Araştırma sonucunda, örneklem grubunu oluşturan meslek elemanlarının gerek aldıkları eğitimin niteliği ve niceliği gerekse mesleki anlamda iş doyumu ve yeterliliği konularında problemlerle karşı karşıya kaldıkları görülmüştür.

Anahtar Sözcükler: Kadın Refahı, İş Doyumu, Mesleki Yeterlilik, Meslek Elemanı

Abstract: It is known that women experience some problems in their working, education and social lives. A lot of studies are made to solve these problems and to enhance women's welfare and employment areas relating to this subject are created. Members of the profession' effect upon the effectiveness and productivity of the studies done to enhance women's welfare are immense. From this position, the aim of this study was to determine the professional competence and job satisfaction of members of the professions working to enhance women's welfare. This research with the characteristic of qualitative research was conducted with 65 members of the profession. Within the scope of this research demographic information concerning the participants was required in the first step and then educational information and expectations before beginning this work, if these expectations had been met or not and, if the participants had obtained extra orientation in the institution. As a result of this research it was found that members of the profession have experienced some problems with both the quality and quantity of the education they received and also with their job satisfaction and profession competence.

Keywords: Women Welfare, Job Satisfaction, Profession Competence, Member of Profession.

\footnotetext{
* Yrd. Doç. Dr., Bursa Teknik Üniversitesi, İnsan ve Toplum Bilimleri Fakültesi, Sosyoloji Bölümü, Bursa. ipekbeyzaaltiparmak@ hotmail.com

** Arş. Gör., Ahi Evran Üniversitesi, Fen-Edebiyat Fakültesi, Sosyoloji Bölümü, Kırşehir. aktas_glcn@hotmail.com

**** Arş. Gör., Hacettepe Üniversitesi, İktisadi İdari Bilimler Fakültesi, Sosyal Hizmet Bölümü, Ankara. yasemin.ertan@hacettepe.edu.tr
} 


\section{Giriş}

Toplum içerisinde dezavantajlı bir konuma sahip olan kadınlar kendilerine biçilen roller ile politikadan iş hayatına kadar pek çok alanda cinsiyet ve firsat eşitsizliklerine maruz kalmaktadırlar (Dolu 2015, 526). Bu noktada sosyal devlet olmanın bir özelliği olarak kadınların problemlerini çözmeye ve ihtiyaçlarını karşılamaya yönelik hizmetler sunulmaktadır. Burada devletler tarafından çeşitli istihdam alanları yaratılmakta ve çalışan meslek elemanları aracıl1ğıyla bu sorunlara yönelik çözüm üretilmeye çalışılmaktadır (Güler 2006, 30; Dedeoğlu 2009, 44).

Kadınların yaşadıkları mağduriyetler akademik literatürde uzun yıllardır ele alınan ve tartışılan konular arasında yer almaktadır. Ancak mesleki anlamda gerek kadınların gerekse diğer dezavantajlı grupların refahını artırmaya ve onların problemlerine çözüm üretmeye yönelik çalışan meslek elemanlarına yönelik yapılan çalışmalar sınırlı sayıdadır. Bu bağlamda toplum içerisinde önemli bir sorun oluşturan, ancak daimi çözümlerin üretilemediği konularda profesyonel anlamda mesleki faaliyet yürüten bireylerin mesleki yeterliliklerinin ve iş doyumlarının belirlenmesi, eksikliklerin ortaya çıkarılarak çeşitli önerilerde bulunulması ve yapılan hizmetlerin etkinliğinin artırılması noktası büyük önem taşımaktadır.

Yapılan araştırmada da kadın refahını artırmaya yönelik çalışan meslek elemanlarının iş doyumları ve mesleki yeterlilikleri belirlenmeye çalışılmıştır. Araştırmanın ilk kısmını oluşturan teorik bölümde iş doyumu kavramının genel bir tanımı ve iş doyumuna etki eden faktörler ile mesleki yeterlilik kavramı ele alınmıştır. Sonrasında ise araştırmanın amaç ve önemi, sınırlılıkları ile verilerin toplanması ve analizi konularına yer verilmiş, üçüncü kısımda araştırma sonuçlarında elde edilen bulgular analiz edilmiştir.

\section{Teorik Çerçeve}

\section{İş Doyumu Kavramı ve İş Doyumuna Etki Eden Faktörler}

Verimliliğin en üst seviyede sağlanması hemen her kurumun öncelikli hedefleri arasında sayılmaktadır. Bu hedefe ulaşabilmenin de temel olarak mesleki anlamda iş doyumuna sahip çalışanlar aracılığıyla sağlanabileceği düşünülmektedir. Bu noktadan hareketle, son y1llarda iş doyumu konusunda çeşitli çalışmaların yapıldığı göze çarpmaktadır (Judge \& Larsen 2001, 67; SousaPoza \& Sousa-Poza 2000, 518). Yapılan bu araştırmalarda farklı bakış açılarına göre ele alınan kavramın çeşitli tanımlamaları ile karşılaşılmaktadır.

En genel haliyle iş doyumunun çalışanların işlerine ilişkin hisleri ve davranışları olarak tanımlandığı görülmektedir. Bu noktada iş doyumu kavramının çalışanların işlerinden beklentileri ile işlerinden gerçekte elde ettikleri, ona atfettikleri önem ve değer arasındaki ilişkiden doğduğu düşünülmektedir (Pushpakumari 2008, 90; Ko 2012, 1004). İş doyumu aynı zamanda çalışanların iş ortamlarındaki yaşanmışlıkları ile işleri hakkındaki şu anki izlenimlerini belirlemeye yönelik bir tutum ölçümü olarak açıklanmaktadır (Robbins \& Coulter 1996, 463). Başka bir bakış açısına göre de iş doyumu, bireyin kendi işi hakkında yaptığı değerlendirmelerden ibarettir (Katzell 1964, 342).

İş doyumunu etkileyen etmenler ele alındığında işle alakalı hemen her konunun iş doyumu üzerinde bir etkisi olduğu söylenebilir. Bu noktada iş doyumunun farklı değişkenler üzerinden ele alındığı göze çarpmaktadır (Pushpakumari 2008, 91). Bazı araştırmacılar bireylerin işlerine yönelik tutum ve davranışlarını, başka bir ifadeyle iş doyumunu ölçebilmek için içsel ve dışsal doyum olmak üzere iki boyutlu bir analiz yapmaya ihtiyaç duyulduğunu savunmaktadırlar (Judge \& Larsen 2001, 68-69). Bu bağlamda içsel iş doyumunu bireyin başarısı, bağımsızlığı 
gibi durumlar etkilerken; dışsal iş doyumu alınan ücret, promosyonlar, iş arkadaşları ile arasındaki ilişki ve çalışma ortamından etkilenmektedir (Mount \& Barlett 2002, 35). Başka bir bakış açısına göre ise iş doyumunu etkileyen etmenler bireysel ve çevresel veya doyum ve doyumsuzluğa yol açan etmenler başlıkları altında açıklanmaktadır (Ceylan, Gül \& Öksüz 2016, 48). İlk grupta yer alan bireysel etmenler; bireyin kişisel özelliklerini de içeren cinsiyet, yaş, eğitim düzeyi, çalışanın kişiliği, medeni durumu, ücret ve çalışma süresini içermektedir. İkinci grup ise statü, işverenin mesleği, ödüller, çalışma koşulları, hizmet için eğitim ve meslek seçimi gibi etmenlerden oluşmaktadır (Lam, Zhang \& Baum 2001, 157; Ceylan, Gül \& Öksüz 2016, 48).

İş doyumunun bireyin çalışacağı işi seçmeye başladığı anda belirlendiğini savunan araştırmalar da mevcuttur. Zira bireyin seçtiği işin kendi ilgi ve yeteneklerini karşılıyor olması, bireyin işine yönelik olumlu duygular ve tavırlar geliştirmesini, başka bir ifadeyle iş doyumuna ulaşmasını sağlayacaktır. Bireyin iş doyumunun yüksek seviyede olması şu anki çalışma potansiyelini de olumlu yönde etkileyecek ve bireyin performansında artış sağlayacak ve hatta kariyerini geliştirme noktasında da önemli katkılarda bulunacaktır (Ko 2012, 1004). İş doyumunun birey üzerinde başka etkilerinin olduğu da göze çarpmaktadır. Konu üzerinde yapılan araştırmalar yaygın bir kabul olan "mutlu çalışan verimli çalışandır" anlayışının geçerliliğini göstermektedir. Zira iş doyumuna sahip bireylerin çalışma performanslarının da yüksek olduğu ve hatta iş ortamında doyum sağlayan bireylerin sosyal hayatlarında da doyum sağladıkları belirtilmektedir. Tam tersi durumda, başka bir ifadeyle insanların iş doyumu sağlayamadığı durumlarda gerek iş ortamında gerekse sosyal hayatlarında geri çekilme eğiliminde oldukları düşünülmektedir (Saari \& Judge 2004, 398-399).

İş doyumu kavramına ilişkin genel bilgilerin ardından kadınların refahını artırmaya yönelik çalışan meslek elemanlarının iş doyumu ile ilgili yapılan çalışmalar ele alındığında, özel olarak bu meslek elemanlarına ilişkin çalışmaların yapılmadığı görülmektedir. Ancak sosyal çalışmacılar gibi belirli meslek gruplarının iş doyumuna ilişkin yapılmış araştırmalar mevcuttur. Örneğin Ceylan, Gül ve Öksüz (2016, 64-67), sosyal çalışmacıların iş doyumları ve tükenmişlik duygularına ilişkin yapmış oldukları araştırmada, araştırmanın örneklem grubunu oluşturan kişilerin bireysel ve örgütsel faktörler başta olmak üzere aldıkları eğitimlere uygun işlerde çalışamamaları gibi hususlardan ötürü problemler yaşadıkları ve bu durumun da bu kişilerin iş doyumunu olumsuz yönde etkilediği sonucuna ulaşmışlardır. Çalışmada özellikle hassas gruplar üzerinde çalışmak zorunda kalan sosyal çalışmacıların yüksek iş doyumu ve daha az tükenmişlik yaşamaları için kurumsal anlamda mesleki gelişimi destekleyici tedbirler alınması gerekliliği ortaya koyulmuştur. Bireysel anlamda da meslek elemanlarının çağdaş evrensel sosyal hizmet yöntem ve tekniklerini yerelle bütünleştiren bilgi birikimiyle mesleki gelişimlerini artırmaları gerekli görülmektedir. Bütün bu bilgiler ışığında, içsel ve dışsal pek çok faktörlerin rol oynadığı iş doyumunun hem kişisel hem de toplumsal pek çok etkilerinin olduğu görülmektedir.

\section{Mesleki Yeterlilik Kavramı}

Bireyin çalışma şartlarının gerektirdiği bilgi, yetenek, güdü ve niteliklere sahip olma derecesi anlamında kullanılan (Kane 1992, 165) mesleki yeterlilik kavramı, aynı zamanda üst düzey yetenekler arasında kabul edilen eleştirel düşünme, takım çalışması, iletişim ve kalıcı öğrenme yeteneklerini de içermektedir (Litcfield, Oakland \& Anderson 2002, 1455). Tipk1 iş doyumu kavramında görüldüğü gibi mesleki yeterlilik kavramı da farklı değişkenlerden etkilenmektedir. $\mathrm{Bu}$ bağlamda mesleki yeterlilik bu değişkenlerin her birinde gösterilen ilerleme olarak da görülmektedir (Vleuten 1996, 42). 
Mesleklerin çalışma şartları ve gerekliliklerinde görülen farklılıklar, o alanda çalışan elemanların sahip olması beklenen mesleki yeterlilik alanlarında da farklılıklara yol açmaktadır. Örneğin; gıda üretimi ve kontrolünde çalışan meslek elemanlarından sağlıklı ve kaliteli gıda üretmelerine ve belirlenen kriterler çerçevesinde kontrollerini sağlamaya yönelik mesleki yeterliliklerinin olması beklenirken (Topliceanu, Bibire \& Nistor 2014, 1034), hemşirelerden hasta bakımının her aşamasını uygulamaktan, hastanın fiziksel ve psikolojik durumunu kontrol altında tutmaya, her hastaya hangi ilacın verileceğine kadar pek çok aşamada mesleki yeterliliklerinin olması beklenmektedir (Gardulf et al. 2016, 168). Bu noktada bahsi geçen meslek gruplarında yeterliliğin daha çok fiziksel, teknik bilgi ve becerilere dayandırıldığı söylenebilir.

Amerika örneği incelendiğinde kadının refahına yönelik çalışan meslek elemanlarından, -en aktif ve geniş kapsamlı bir görev alanı tanımlaması olan-, sosyal çalışmacıların özel bir alanda uzmanlaşmış olmaları ve hem kişisel hem de mesleki anlamda gerekli donanımlara sahip olmaları beklenmektedir. Bu noktadan hareketle sosyal çalışmacılar için başta çocuk refahı veya aile hizmetleri, sağlık, okul, toplum, klinik, endüstri, yaşlılık hizmetleri olmak üzere en az yedi uzmanlaşma alanı belirlenmiştir. Sosyal çalışmacıların bu görevleri yerine getirebilmeleri için insan davranışları ve gelişiminin yanı sıra sosyal, ekonomik ve kültürel kurumların ilişkisi ile ilgili olarak geniş bir bilgi birikimlerinin olması gerekmektedir. Bu sebeple en az lisans eğitimi görmüş olan kişiler sosyal çalışmacı olarak çalışabilmektedir (Garner 2008, 31-34).Bunun yanı sıra bireylerin belirli kurumlarda sosyal çalışmacı olarak çalışabilmeleri için farklı uygulamalara tabi tutuldukları göze çarpmaktadır. Örneğin, bireyin ruh sağlığı alanında hizmet veren bir hastanede sosyal çalışmacı olarak çalışabilmesi için 60 günlük bir eğitim daha almaları gerekli görülmektedir. Bu eğitimde bireyden tez hazırlaması, hukuk sınavına girmesi, farklı seviyelerde belirlenen 38 adet mesleki yeterlilik noktalarını karşılaması beklenmektedir (Douglas \& Philpot 1998, 113).

Sosyal çalışmacıların mesleki yeterlilikleri bağlamında kişisel özelliklerinin ve mesleki geçmişlerinin de önemli bir etkisi olduğu göze çarpmaktadır. Bu noktada bireyin hayat tecrübesi, yeteneklerinin kişisel özelliklerini oluştururken; bireyin inanç sistemi, değerleri, etik ilkeleri gibi hususları da onun mesleki geçmişini şekillendirmektedir. Bu iki etmenin bireyin mesleğinin gereklilikleri ile örtüşmesi önemli görülmektedir. Sonuç olarak, bireyin eğitiminden ve tecrübelerinden elde ettiği bilgiler ile kişisel becerileri ve teknikleri uygulamadaki yeterliliği de mesleki yeterliliğin bir boyutunu oluşturmaktadır (Selcik \& Güzel 2016, 465).Bütün bu bilgiler 1şığında hemen her meslek grubunda yer alan bireylerden beklenen mesleki yeterliliklerin farklılık gösterdiği sonucuna ulaşılabilir. Bu noktada özellikle kadınlar, çocuklar gibi dezavantajlı gruplarla ilgili konular üzerinde çalışan meslek elemanlarının mesleki yeterliliklerinin ve iş doyumlarının analiz edilmesi önem arz etmektedir.

\section{Araştırmanın Önemi}

\section{Amaç ve Önem}

Türkiye'nin son y1llarda içerisine girdiği değişim ve dönüşüm içeren süreçte birçok alanda yenilik meydana gelmiştir. Siyasal, sosyal ve ekonomik olarak her bakımdan revize edilen birçok alan ve beraberinde topluma dair artan sorunlar, meslek elemanlarına olan ihtiyacı artırmıştır. Bu ihtiyaç beraberinde dezavantajlı gruplarla çalışan meslek elemanları içinde yoğun bir çalışma temposu yaratmış ve uzmanlaşmış personele olan ihtiyaç artmıştır. Kadınların refahını artırmaya yönelik çalışan meslek elemanlarının toplumsal sorunlara sağladıkları katkı ve üstlendikleri rol ele alındığında önemli bir görev yaptıkları görülmektedir. $\mathrm{Bu}$ açıdan bakıldığında, işleyişin daha iyi ve daha verimli olabilmesi kuşkusuz çalışanın mesleki doyum 
sağlayabilmesine ve kendi eğitim ve donanımına uygun çalışabilmesine bağlıdır. Hiç kuşkusuz bunun olabilmesi için bu meslek grubunun yaşadığı sorunların üzerine eğilmek önemlidir (Ceylan, Gül \& Öksüz 2016,46).

Bu noktada çalışmanın temel amacı, kadınların refahını artırmaya yönelik çalışan meslek elemanlarının mesleki yeterlilik ve iş doyumunu incelemektir. Meslek elemanlarının işlerini yaparken karşılaştıkları zorluklar, aldıkları eğitimin meslek uygulamasına katkısı yönündeki düşünceleri, kendilerini alanda nasıl gördükleri gibi konular üzerinde durulacak ve soruna ilişkin öneri ve görüşlere yer verilecektir. Çalışmanın bu yönüyle alana dair farklı sorunları ortaya çıkaracağ 1 ve ileride yapılacak çalışmalara yol gösterici olacağı düşünülmektedir.

\section{Araştırmanın Sınırlılıkları}

Yapılan çalışmanın birtakım sınırlılıkları bulunmaktadır. Çalışma Marmara, İç Anadolu ve Karadeniz bölgelerini kapsamaktadır. Kuşkusuz örneklem kitlenin sayısının çoğaltılması ve diğer bölgelere de ulaşılmasıyla araştırma daha kapsayıcı bir hale gelecektir. Çalışan personelin mesleki problemleri, bölgelerin özelliklerine ve o bölgenin sosyal yapısına göre çeşitlenecektir. Bu bakımdan farklı bölgelerde çalışan meslek elemanlarının çalışmaya dâhil edilmesi araştırmaya farklı boyutlar kazandıracaktır. Bunların yanı sıra çalışma konuyu sosyolojik bir boyutta ele almış ve çalışanların ekonomik düzeyleri üzerinde durulmamıştır. Ekonomik olarak tatmin ve doyum çalışma kapsamı dışında bırakılmıştır.

\section{Verilerin Toplanması ve Analizi}

Kadınların refahını artırmaya yönelik çalışan meslek elemanlarının mesleki yeterlilik ve iş doyumuna yönelik yapılan çalışma nitel araştırma özelliği taşımaktadır. Çalışma kapsamında ilk olarak literatür taraması yapılmıştır. Gerekli yazılı kaynaklara ulaşıldıktan sonra çalışmada öncelikli kaynaklar belirlenmiş ve problemin çerçevesi oluşturulmuştur. Alan verileri derinlemesine mülakat yapılarak elde edilmiştir. Araştırmanın örneklemini Marmara, Karadeniz ve İç Anadolu Bölgesinde özel ve kamu kurumlarında görev yapan meslek elemanları (sosyolog, psikolog ve sosyal hizmet uzmanı vb.) oluşturmaktadır. Çalışma kapsamında hazırlanan görüşme soruları araştırmacılar tarafından bizzat uygulanmış ve toplamda 65 meslek elemanıyla görüşülmüş̧ür. Meslek elemanlarına kartopu örnekleme yöntemiyle ulaşılmıştır. Kartopu örnekleme, örneklemin aşamalı olarak çekilmesidir (Aziz 2014,55). Katılımcılara mülakat öncesi konuyla ilgili ön bilgilendirme yapılmış ve görüşmeler yaklaşık 20-30 dk. aralığında sürmüştür. Görüşmelerin tamamında gönüllülük ilkesi esas alınmış olmakla birlikte, çalışma Ocak ve Mayıs 2017 tarihleri arasında gerçekleştirilmiştir.

Çalışmada, teorik açıklamaların sonrasında alan çalışmasının sonuçlarına yer verilmiştir. Elde edilen veriler, 'kategorik bağlamsal çözümleme tekniği' (Categorical-Content Perspective) kullanılarak analiz edilmiştir. Bu bağlamda öncelikle mülakat formuna göre veriler toplanmış ve daha sonra bu veriler gerekli okumalar yapılarak yazılı metin haline getirilmiştir. Bu metinler daha sonra alt kategorilere ayrılmış ve konu başlıkları netleştirilmiştir (Lieblich, TuvalMashiachand \& Zilber 1998, 112-113). Bu noktada görüşülen kişilerin her birine gizliliğin korunması için G. K. (görüşülen kişi) kısaltmasıyla numaralar verilmiştir. Görüşme metinleri birebir konuşmacının ağzından çıktığı şekliyle aktarılmış ve hiçbir değişiklik yapılmamıştır.

\section{Bulgular}

Araştırmanın bulgular kısmında çalışma verileri analiz edilmiştir. Bu noktada elde edilen veriler çözümleme içeriği oluşturularak üç ana başlık altında toplanmıştır. İlk olarak görüşülenlerin sosyo-demografik özellikleri değerlendirilmiştir. İkinci olarak mesleki doyum ve yeterliliğe 
yönelik analizlere yer verilmiş, beklenti ve deneyimler ele alınmıştır. Son olarak görüşülen meslek elemanlarının görüş ve önerilerine yer verilmiştir.

\section{Görüşülenlerin Sosyo-Demografik Özellikleri}

Yapılan çalışma kapsamında ilk olarak görüşülenlerin sosyo-demografik özellikleri ele alınmıştır. Konuyla ilgili olarak görüşülen meslek elemanlarının \%82'si kadın ve \%18'i erkektir. Ulaş1lan meslek elemanlarının daha çok kadın refahına yönelik çalışma yapan kurumlarda çalıştığı düşünüldüğünde örneklem kitlede daha çok kadınların yer alması kaçınılmazdır. Yaş aralıkları incelendiğinde ise görüşülenlerin \%71'inin 20-30 yaş aralığında, \%28'inin 31-40 yaş aralığında ve \%1'inin ise 41-50 yaş aralığında yer aldığı saptanmıştır.

Tablo 1. Örneklemin Sosyo-Demografik Özellikleri

\begin{tabular}{|c|c|c|}
\hline & Sayı & Yüzde (\%) \\
\hline \multicolumn{3}{|l|}{ Cinsiyet } \\
\hline Kadın & 53 & 82 \\
\hline Erkek & 12 & 18 \\
\hline \multicolumn{3}{|l|}{ Toplam: 65 (100) } \\
\hline \multicolumn{3}{|l|}{ Yaş } \\
\hline $20-30$ & 46 & 71 \\
\hline $31-40$ & 18 & 28 \\
\hline 41-50 & 1 & 1 \\
\hline \multicolumn{3}{|l|}{ Toplam: 65 (100) } \\
\hline \multicolumn{3}{|l|}{ Doğum Yeri } \\
\hline İl & 47 & 72 \\
\hline İlçe & 10 & 16 \\
\hline Köy & 8 & 12 \\
\hline \multicolumn{3}{|l|}{ Toplam: 65 (100) } \\
\hline \multicolumn{3}{|l|}{ Medeni Durum } \\
\hline Evli & 25 & 39 \\
\hline Bekâr & 40 & 61 \\
\hline \multicolumn{3}{|l|}{ Toplam: 65 (100) } \\
\hline \multicolumn{3}{|l|}{ Eğitim } \\
\hline Yüksek okul & 1 & 2 \\
\hline Lisans & 54 & 83 \\
\hline Yüksek lisans & 10 & 15 \\
\hline Toplam: 65 (100) & & \\
\hline
\end{tabular}

Yapılan çalışma kapsamında görüşülenlerin doğum yerinin neresi olduğu sorulmuş ve alınan cevaplar sonucunda \%72'sinin il, \%16'sının ilçe ve \%12'sinin köy doğumlu olduğu görülmüştür. Medeni durum incelendiğinde \%39'unun evli ve \%61'inin bekar olduğu saptanmıştır. Yaş 
aralıkları göz önünde bulundurulduğunda daha çok genç yaşlarda çalışanların olması sebebi ile bekâr oranının yüksek olması paralellik göstermektedir. Eğitim seviyesi ele alındığında ise $\% 83$ 'ünün lisans, \%15'inin yüksek lisans ve $\% 2$ 'sinin ise yüksekokul mezunu olduğu görülmüştür.

Tablo 2. Mezun Olunan Bölüm

\begin{tabular}{|c|c|c|}
\hline Bölüm & Sayı & $\begin{array}{c}\text { Yüzde } \\
\%\end{array}$ \\
\hline Sosyoloji & 24 & 37 \\
\hline Sosyal Hizmet & 18 & 28 \\
\hline Psikoloji & 14 & 21 \\
\hline Çocuk Gelişimi & 7 & 11 \\
\hline Öğretmenlik & 2 & 3 \\
\hline Toplam & 65 & 100 \\
\hline
\end{tabular}

Meslek elemanlarının mezun oldukları bölümler incelendiğinde en yüksek oranın \%37 ile sosyoloji bölümü mezunu olduğu görülmektedir. Bunun yanı sıra \%28'i sosyal hizmet, \%21'i psikoloji, \%11'i çocuk gelişimi, \%3'ü öğretmenlik mezunudur.

\section{Mesleki Doyum ve Yeterlilik}

Çeşitlenen ve giderek artan sosyal problemler meslek elemanlarına olan ihtiyacı artırmıştır. Dezavantajlı gruplarla çalışan ve mesleki bilginin yanı sıra aynı zamanda manevi fedakârlık gerektiren bu meslek grubuna yönelik çalışmalar oldukça önemlidir. Bunula beraber güçlendirme ve bilgilendirme çalışmaları kapsamında söz konusu meslek grubuna yönelik saptamalar yapmak gereklidir. Çalışan personelin kendini yeterli hissetmesi ve yaptığı işten tatmin olması, daha verimli bir çalışma ortamını doğuracak ve hedef kitleye daha etkili bir hizmet sunumunu sağlayacaktır (Ceylan, Gül \& Öksüz 2016, 46). Buradan hareketle mesleki doyum ve yeterlilik kapsamında değerlendirilecek veriler ilk olarak görüşülenlerin "Okuduğunuz bölümü neden seçtiniz?" sorusuyla başlamaktadır. Bu noktada çeşitli görüşler mevcuttur:

G.K.37. "Arkadaşlarımın hayatlarında karşılaştıkları zorluklara pratik çözüm önerileri ile onlar motive ettiğimi, sorunlarına çözüm odaklı yaklaşabildiğimi, empati kurmayı sevdiğimi, iyi bir gözlemci olduğumu ve etkin dinlemeyi başarabildiğimi fark ettim. Bu da mesleğimle doğru orantıl bir yaklaşımdı ve bunu rehber ögretmenimle birlikte değerlendirdiğimizde bu bölümü yazmamın bana uygun olacă̆ını düşündüm”.

G.K.7. "Insanlara yardım etme isteği ve ilgi alanlarımla örtüşmesi sebebiyle böyle bir alanda çalışmak istedim ve bu bölümü tercih ettim”.

G.K.26. "Kültür, ekonomi, siyaset gibi pek çok dalı içerisinde barındırdiğı için bu bölümü seçtim. Benim çok yönlü ilgilerime hitap ediyordu”.

G.K. 48. "İlgi ve eğilimim bu yönde olduğu için seçtim. Sosyal bilimlere genel anlamda bir ilgim vardır ancak bunların içinde çalışma alanı olarak sosyoloji en çok ilgimi çeken alandır"

G.K. 61. "İnsan ilişkilerine önem verdiğim için ve merak etmem, ilgimi çekmesi gelecekte ihtiyaç duyulan ve önü açık bir bölüm olması benim 
hoşuma gitti”.

G.K. 31. “...Bana hitap eden alanı bulmam için yeterince seçenek olduğunu düşündüm. Yani beklentilerimden birisi mesleğin kendi içindeki çeşittiliğiydi. Bölümü araştırırken iş imkânları konusunda (o zamanlar) meslek elemanına en çok ihtiyaç duyulan meslek olması nedeniyle mezuniyetten sonra çok zorlanmadan iş bulma beklentim vardl. Son olarak da anlamlı bir is yapmay istiyordum. Birilerinin hayatında onların yararına olacak şekilde değişimler yaparak hem onları memnun etmeyi hem de böylece kendimi mutlu etmeyi umuyordum".

G.K. 65. "Sosyal hizmet alanlarının çok yönlü olmasından dolayı bu bölümü okumak istedim. Mesleğimin en güzel yanının bu olduğunu düşünüyorum".

G.K. 24. “...Merak ettiğim alanlardan biriydi, ancak önceliğim değildi. Ülkenin koşullarını düşündüğümde tercih ettim”.

Genel olarak değerlendirildiğinde bölüm seçiminde çeşitli etkenlerin rol oynadığı, ancak bir belirsizlik olmadığı görülmektedir. Kişiler okudukları bölümü kendi ilgi ve istekleri doğrultusunda okumaya karar vermişlerdir. Bu noktada görüşülenlerin eğitim almadan önce yaptıkları tercihlerin tesadüfi olmadığ 1 ve bilinçli tercihlerle bölümlerin seçildiği görülmüştür.

\section{Beklenti ve Mesleki Doyum}

Görüşülenlerin çoğunlukla bilinçli olarak alan seçimi yaptığının saptanması üzerine bu alandan beklentilerin neler olduğu sorgulanmıştır. Bu noktada ilk olarak "Mesleğe başladığınızda yaptığınız işten beklentileriniz nelerdi? ” sorusu yöneltilmiştir.

G.K. 23. "Dezavantajlı olduğunu düşündüğüm tüm gruplar için çalışmalar yapıp, bulunduklar duruma olumlu yönde katkalar sağlamak ve sorun olarak düşündüğ̈̈m tüm durumlara kalıcı çözümler bulmak benim için önemliydi”.

G.K. 33. “...Mesleki örgütlenmenin oldukça güçlü olduğunu düşünüyordum".

G.K. 62. "Bu meslekten asll beklentim dezavantajlı kesimlere hizmet sunarken onların kendi sorunlarını kendi başlarına çözebilecekleri şekilde güçlendirmelerini sağlamaktı. Bu meslek sadece hizmet değil aynı zamanda uslah yöntemlerini de içeren ve her toplum için sosyal refah ve sosyal adaletin sağlanmast için gerekli olan bir meslektir. Ülkemizde ve dünyada hak ettiği değeri görmesini istiyorum. Bu mesleği icra ederken karşılaşılan bürokrasi vb. engellerin en asgari düzeye indirilmesi, özellikle hizmet sunumu sırasında hizmetin tarafsızlığına ve etikliğine gölge düşüren etkilerin ortadan kaldırllması mesleki anlamda en önde gelen beklentilerimdendir".

G.K. 4. “...Şu anda idareci olarak çalışmakla birlikte çalıştığım alanda kesinlikle idarecilik yapmak istememekteyim. Mesleki olarak en büyük beklentim bizi anlayan ve mutlu olacağımı yerde çalışmamıza imkan veren yerde çalışmak".

G.K. 24.” Karşılanmadı. Ben bir psikoloğum benim bakış açım mevzu- 
atla çatışıyor. Şöyle ki; mevzuat gereği yapmam gereken 6284 sayılı kanundaki kadınlar hakkında koruyucu önleyici tedbirleri sağlamak, ancak bir psikolog olarak kadınlarla devaml görüşmeler yapabilmek farklı terapi tekniklerinden yararlanmak ve ruhsal açıdan iyileştirmekti. Bunları gerçekleştirmekti. Kadınlarla 1-2 kez görüştüm. İhtiyaç ve durum tespiti var çözüme yönelik etkim yoktu. Sosyal hizmet uzmanı gibi davrandım ama beklentim psikolog olarak müdahalede bulunmaktı".

Yapılan görüşmeler analiz edildiğinde bireylerin beklentilerini; dezavantajlı görülen gruplara katkı sağlamak, güçlü bir mesleki örgüt içerisinde çalışmak, okuduğu alana dair sahip olduğu bilgi ve ilgi bağlamında iş yapmak, güçlendirme çalışmaları yürütmek ve çözüm odaklı müdahalelerde bulunabilmek olarak sıralayabiliriz. Söz konusu beklentilerin karşılanıp karşılanmadığı ele alındığında durum değişmektedir. Mesleğe başladığında sahip olduğu beklentilerin karşılanmadığını düşünen katılımcılar bu görüşlerini şu şekilde ifade etmiştir:

G.K. 26. "Mesleğe başladıktan sonra pek çok meslek grubunun aynı pota içerisinde eritildiğini, hizmet modellerinin alanla ilgisini kısıtlı bulduğum kişiler tarafindan geliştirildiğini, bu modeller konusunda hizmet alıcılarından gelen dönütlere göre gerekli değişimin sağlanmadiğını izledim. Kurumlararası diyaloğun sinırlı olduğunu, kurumların birbirini tanımadı̆̆ını ve kurumlar içerisinde meslek gruplarının da birbirini tanımadiğını, yönetmeliklerde yer alan mesleki görevlerin işlevsiz oldugunu anladım”.

G.K. 42. "Hayır karşılanmadı çünkü aldiğım eğitim ile yaptı̆̆ım iş arasinda profesyonel bir bağlantı yok".

G.K. 10. "Mesleğe başladıktan itibaren beklentilerimi gözden geçirdim. Beklentilerim benim fazla eforumla minimal düzeyde karşılaniyordu ve bu benim için çok yorucu bir süreçti. Insanların değişiminin kolay olmayacă̆ını ve öncelikle aldığım eğitimle işe kendimden başlamam gerektiğini anladım. Bu nedenle beklentilerimi düşürerek daha kabullenici olmaya başladım”.

Yapılan mülakat sonrasında konuyla ilgili çeşitli düşünceler ortaya koyulmuştur. Sebepler arasında en çok vurgu yapılan konu, alınan eğitim ile yapılan işin örtüşmemesi noktasında karşımıza çıkmaktadır. Görüşülen meslek elemanları yaptıkları işin aldıkları eğitim bağlamında değil, pek çok meslek grubunun yapabileceği bir kategoride değerlendirildiğini belirtmişlerdir. Yapılan mülakat esnasında bazı meslek elemanlarının beklentilerinin karşılanmaması sonucu ortaya çıkan durumu kabullenmiş oldukları gözlemlenmiştir. Gelinen son noktada konuyla ilgili düzenlemelerin yapılması ve bu düzenlemelerin eğitim yıllarından başlayarak alana ilişkin uzmanlaşma noktasından başlaması gerekliliği karşımıza çıkmaktadır.

\section{Mesleki Yeterlilik}

Kadın refahına yönelik çalışan meslek elemanlarının geniş bilgi ve beceriye sahip olmasının yanında sahip oldukları mesleki deneyim ve tecrübe oldukça önelidir. Buradan hareketle söz konusu alanda yapılan uygulamaları kimin ve nasıl yaptığı oldukça önemlidir. Çalışanın kendine duyduğu yeterlilik hissi ve özgüven sistematik bir bilgi birikimi gerektirmektedir (Genç \& Barış 2015, 99). Buradan hareketle mesleki yeterlilik kapsamında görüşülenlere ilk olarak "üniversitede aldıkları eğitimin çalışma hayatında yeterli olup olmadı̆̆ı" hakkındaki fikirleri 
sorulmuştur. Bu soruya verilen cevaplar aslında durumun farklı bir çalışma alanı olarak detaylı bir şekilde ele alınabileceğini ortaya koymuştur.

G.K. 23. "Hayır. Eğitimin teorik olması, uygulamaya yönelik çalışmaların az olması iş hayatında zorlanmama neden oldu”.

G.K. 5. "Üniversitede suçla ilgi aldı̆̆ım eğitimin yeterli olmadı̆̆ını düşünmekteyim. Mesleğe başladıktan sonra hedef grupla yapacağımız çalışmalara yönelik aldığım grup çalı̧̧ması eğitimlerinin olumlu olduğu ve devaml olması gerektiğini düşünüyorum”.

G.K. 29. "Bence oldu, ancak çalıştı̆̆ımız ortamlara göre bilgiyi kullanıp kullanamama kısmı eksik kaldı. Burada sadece bizim bilgili olmamı değil, çalıştığımız kurumun bizi ne kadar tanıdığı ve önemsediği de etkiliydi. Hasta haklarında çalıştığım sürede hiçbir bilgiye gerek yokmuş dediğim zamanlar oldu maalesef. Bunu ... Merkezi için iddia edemem. Çünkü orda daha sistemli bir yapı üzerinde çalışmalar devam ettiği için teorik bilgiyi kullanma şansımı oldu. Tabii ki özel bir alan olması sebebiyle aldı̆̆ımı e ĕitimin eksik kaldı̆̆ını söylemeliyim”.

G.K. 62. "Bunu söylemek zor olsa gerek. Aldı̆̆ım ĕgitimler mesleğin icra edilmesi sırasinda muhakkak çok büyük öneme sahiptir. Ancak bazı noktalarda sorunlar karşısında müracaatçı ile birlikte demoralize olabiliyorsunuz. Ben şahsen karşılaşılan vakaların meslektaşlarımızı fazlasiyla yıprattı̆̆ını, tükettiğini düşünüyorum. Hizmet verdiğimiz kesim düşünüldügü̈nde bunun normal olduğunu söyleyebiliriz. Ancak üniversite ĕgitimi sırasında mesleği icra edeceklerin bu tür sıkıntıların üstesinde daha kolay gelebilmesi için çok daha fazla güçlendirilmesi gerektiğini düşünüyorum. Vaka örneklerinin daha yoğun bir şekilde derslerde konuşulması, tartışılması ve çözüm yollarının ortak akıl ile bulunması gerektiğini düşünüyorum. Meslektaşlarımızı çalışma hayatında zorlayacağını düşündü̈̆̈̈müz vakaların yoğun bir şekilde tartışılıp çözüm yollarının aranması, çalışma hayatında meslektaşlarımıza benzer vakaların gelmesi halinde çok daha kolay üstesinden gelme imkanı sunacağını düşünüyorum”.

G.K. 65. "Teorik bütün bilgiler pratikte uygulanmiyor. Tabii ki öğrendiğimiz bütün çalışma alanların alanda iken biliyor olmak insanı rahatlattyor".

G.K. 21. "İs ortamında yeterli oldu fakat pratikte bazı şeyler teorinin ötesinde olabiliyor. Kişisel duygu ve düşünceler klsmen de olsa işe dâhil edilebiliyor. Bunlar dışında teori ile pratik arasında çok büyük farklar yaşamadım".

Yapılan mülakat çalışması sonrasında gerekli değerlendirmeler yapıldığında, lisans döneminde daha çok teoriye dayalı dersler alındığ 1 ve bunun sonucunda uygulama noktasında yetersiz kalınabildiği yönündeki görüşler ağır basmaktadır. Birçok meslek elemanı vaka analizine yönelik daha fazla uygulamalı örnek üzerinden dersler verilmesi ve çalışma hayatında vakalara yönelik sorun çözebilecek yeterlilikte bilgi ve donanıma sahip olunması gerektiğine yönelik görüş bildirmiştir. Yine bu alanda çalışan elemanların güçlendirilmesi bir diğer önemli husus olarak karşımıza çıkmaktadır. Zor ve yoğun olarak çalışılan bir alan olduğu düşünüldüğünde, 
vakaya yönelik güçlendirme hizmetlerinin yanı sıra vaka ile çalışmayan ama kadınlara yönelik farklı hizmetleri gerçekleştiren elamanlara da birtakım hizmetlerin verilmesi sürecin daha etkin ve yetkin sürdürülebilmesi adına büyük bir önem taşımaktadır.

Alınan eğitimin yeterli olup olmadığ 1 yönünde farklı bir görüş de yüksek lisans yapan uzmanlardan gelmiştir. Görüşülen uzmanların yüksek lisans eğitiminin vaka yönetimi sürecine katkısı olduğu yönünde çıkarımları mevcuttur.

G.K. 32. "Lisans eğitiminin çok fazla olmasa da yüksek lisans eğitiminin çok daha fazla katklsı olmuştur".

G.K. 59. "Lisans eğitiminde bütüncül eğitim aldı̆̆ımız için bir çerçeve çizildi ancak bunu kişisel becerilerle ve devamında eğitim programları, lisansüstü eğitim ile desteklenmesi daha sağllklı ve faydalı olacaktır".

Konuyla ilgili olarak lisans programlarının değerlendirilmesi yapılırken meslek elemanlarının yüksek lisans yapmaya teşvik edilmesi ve bu sürecin olumlu bir şekilde desteklenmesi de ayrı bir önem taşımaktadır. Böylece daha donanımlı bir personel ile çalışılacak ve aynı zamanda söz konusu uzmanların kendilerini geliştirebilecekleri ilgileri doğrultusunda bir alanda ilerlemeleri sağlanacaktır. Çalışanın ilgileri doğrultusunda bir alanda kendini geliştirmesi, onu aynı zamanda iş yaşamının da monotonluğundan ve yoğun stresinden biraz olsun uzaklaştıracaktır. Bu konuda görev sadece meslek elemanlarına değil, aynı zamanda kurum yöneticilerine de düşmektedir.

Kurum yöneticileri tükenmişlik ya da iş doyumsuzluğu yaşayan personeli bir noktada iyi gözlemlemeli ve gerekli müdahaleyi yapmalıdır. Aksi takdirde çalışan hem kurum hem de vaka açısından verimli olmayacak aksine süreç içerisinde iş yapma isteğini kaybettiği için birtakım sorunlara neden olacaktır (Ertürk \& Keçecioğlu 2012, 52). Nitekim Danış ve Genç tarafindan yapılan "Kurumsal Bakım Elemanlarının Genel Özellikleri ve Yaşadıkları Sorunlar" adlı çalışmada 50 bakım elemanıyla yüz yüze görüşülmüş ve çalışanların en çok stres sorunu yaşadıkları sonucuna ulaşılmıştır (Danış \& Genç 2011, 178-179). Çalışılan alan ile ilgili olarak gerekli bilgilendirmelerin yapılması ve problemlerin paylaşılması, personelin üzerindeki stresi azaltmaya yardımcı olacaktır. Burada gerçekleştirilecek oryantasyon çalışmaları önem kazanmaktadır. Görüşülen kişilerin bir kısmı çalıştığı alanla ilgili olarak oryantasyon eğitimi almadığını belirtmiştir:

G.K. 62. "Benim çalıştığım kurumda ve bağll kuruluşlarında oryantasyon sadece bir doysa içerisindeki bir kaç sayfa yazıdan ibaret tabi bunun dahi tüm kuruluşlarda olmadığını düşünüyorum. Çalışma alanlarında meslek elemanı yetersizliği ve yerleşmiş bazı kalıplar mesleğe başlayanların meslek hayatının ilk günü en zorlu vakaların içerisinde bulabiliyor kendini. 'Kervan yolda düzülür' mantığı maalesef çok derin kökleri olan ve sökülüp atılması zor olan bir kalıp. Meslektaşlarımıza oryantasyon yerine yanlı̧̧ yapa yapa doğruyu öğreneceği söylenerek direkt olarak vakaya dahil ediliyor. Bence meslektaşlarımızın çok kısa sürede tükenmişlik yaşamasinin en önemli sebebi bu”.

G.K. 59. "Oryantasyon yapıldı̆̆ını biliyorum ancak henüz dahil olmadım. Yapılan eğitimin sanal ortamda, uzaktan eğitim aracılığı ile yapıldığın biliyorum".

G.K. 1. "Bu konuda ilginç bir deneyimim vardır. Çalıştı̆̆ım kurumda giriş yaptığımın ertesi günü tek başıma alan uygulamasına çıktım ve çok 
zor bir vaka hakkında sosyal inceleme raporu yazmam istendi. Vakanin ne olduğunu, dosya içeriğinde neler olduğunu bile bilmeden dosyayı sadece görüşme yapacağım aileyi ziyarete giderken yolda okudum. Hiçbir oryantasyon çalışması olmadı maalesef. Fakat çalıştı̆̆ım kurumda mevcut meslektaşlarımdan destek almaya çalıştım, tıkandı̆̆ım konularda deneyimlerine başvurdum".

G.K. 6. "Kurumda herhangi bir oryantasyon çalışması yapılmadı. Belki yapılması çok daha iyi olabilirdi".

G.K. 27. "Yapılmıyor. Hatta iş öğretmeden ilk gün iş verdiler".

Lisans döneminde alınan eğitimin daha fazla teori içerdiği yönündeki saptamalardan sonra kurumların sağladığı oryantasyon eğitimi kuşkusuz daha fazla önem kazanmaktadır. Eğitim almayan uzmanların konuyla ilgili açıklamaları mevcuttur. Bu noktada yetersiz görülen teorik eğitimden sonra uzmanların bazılarının hemen alana çıktığı görülmüştür. Ayrıca yapılan mülakatlar sırasında konuyla ilgili sıkıntıların daha çok uzmanların kendileri tarafından karşılandığı, ayrıca yardım talep edilerek vakaya yönelik birtakım problemlerin üstesinden gelindiği görülmüştür.

Oryantasyon almayan uzmanların yanı sira alanlar da mevcuttur. Bu yorumlar değerlendirildiğinde aldığı eğitimden memnun olan çalışanların yanı sıra, aldığı eğitimi yetersiz bulan çalışanlarda mevcuttur. Sonuç olarak oryantasyon alan çoğunluğun eğitimden faydalandığ 1 görülmüsşür. Konuyla ilgili olarak verilen oryantasyon eğitiminin her kurumda uygulanmasının faydalı olacağı açıktır.

G.K. 26. "Mesleğe başladı̆̆ım dönemde kurumun hizmetleri hakkında bilgilendiren eğitimler gerçekleşmiş̧tir. Bunun yanında deneyimli meslek elemanları alanı tanıma ve müracaatçılarla iletişim konusunda bir süre destek vermiştir. Ancak bunların yeterli olmadiğını düşünmekteyim”.

G.K. 16. "Eğitim aldım. Oldukça faydalı oldu, bence her çalışan almalı".

G.K. 25. "İlk işe başladığım dönemde ...hizmetinin nasıl verildiğine dair memur ve uzman kişilerden bilgiler aldım. Sistemleri kullanma, resmi dilde yazı yazma gibi işleri de sora sora öğrendim. İşime yaradı".

G.K. 22." Oryantasyon yapıllyor. İlk işe başladı̆̆ımızda yapacă̆ımız iş ile ilgili oryantasyon yapıld. Dönem dönem de kurumumuzda mesleki eğitimler verilmekte".

G.K. 39. “Aile ve Sosyal Politikalar Bakanlığı'nın işe ilk başladığımız zamanlarda kurumu tantmak, işleyişi anlatmak ve adaptasyon için yapmış olduğu bir oryantasyon çalışması vardı. Ĕ̈itimlerle oryantasyon çalışmasinı sürdürdüler”.

G.K. 63. "Deneyimli meslek elemanlarindan destek aliyoruz ve Aile ve Sosyal Politikalar Bakanlığ zaman zaman eğitim düzenliyor. Bu eğitimler yararlı oluyor".

Görüşülen meslek elemanlarının mesleği konusunda kendini nasıl gördüğünü ve tükenmişlik durumunu saptamak amacıyla "Işsinizi yaparken kendinizi yeterli hissediyor musunuz?" sorusu yöneltilmiştir. Bu noktada görüşülenlerin öz eleştiri yaparak tüm içtenlikle görüşlerini ortaya koyduğu gözlemlenmiştir. Meslek elemanlarının bir kısmı kendini yeterli gördüğünü, bir kısmı 
ise özellikle bazı alanlarda yetersiz kaldığını belirtmiştir.

G.K. 18. "Klsmen kendimi yeterli hissediyorum".

G.K. 25. "Eğitimimin bazı noktalarda yeterli olmadiğını düşünüyorum çünkü çalıştı̆̆ım alanın uygulamasını burada öğreniyorum. Teorik ĕgitim kadar uygulama ĕgitimi de almalıydık".

G.K. 7. "Kendimi çalıştı̆̆ım işle ilgili genel anlamda yeterli hissediyorum, ancak eğitim ve ögrenme sürekli olması gereken bir süreç. Her zaman öğrenmeye açı̆̆ım.

G.K. 62. “...Kendimi mesleğe bağladı̆̆ım ilk günden bu yana yetersiz hissediyorum. Karşılaştığım vakalar çok daha profesyonel olmam gerektiğini her defasında hissettiriyor. Bence çoğu meslektaşımız yeterli olup olmadiğını düşünecek vakte dahi sahip değil zira iş yükünün fazla olması ve yapılan işin niteliğinin değil niceliğinin göz önünde bulundurulduğu kurumlarımızda işin keyfiyeti değil kemiyeti önem arz

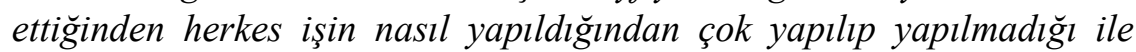
ilgileniyor. Bu ise insanlara kendisini yeterli olup olmadı̆̆ını düşünecek zaman da firsat da istek de birakmıyor, tükenmişlik yaratıyor".

Konuyla ilgili olarak öğrenmenin devam eden bir süreç olduğu ve kendini geliştirmenin önemine dair vurgular mevcuttur. Ancak kendini yeterli hissedip hissetmeme noktasında uzmanlaşmanın tek bir alana yönelik olmaması da oldukça etkilidir. Yapılan görüşmeler sırasında meslekler arası görev paylaşımı ve sınırların belirlenmesine yönelik çıkarımlar oldukça önemlidir.

G.K. 46. "Klsmen, çünkü mesleki sinırlar tam olarak çizilmediği için alanlar karışabiliyor. Alan ayrımı tam olmadı̆̆ için başka alanlarda yetersiz kalabiliyorum. Her konuda iyi olmam mümkün değil”.

G.K. 33. "Mesleğe ilk başladığım aylarda her yere yetişmeye çalıştığım için kendimi yetersiz hissederdim. Çok çeşitli vaka vardl. Şimdi sınırlarımı, yapıp yapmayacaklarımı biliyor ve görevimi doğru yönlendirmelerle hafifletmeye, görev paylaşımını ön plana çıkarmaya çalışıyorum. Vakalarla yeterince, hassasiyetle ilgilenmeye çalışlyorum, kendi üzerime düşeni yapma konusunda evet yeterliyim”.

Her meslek elemanında olduğu gibi söz konusu alanda çalışanlar da işini yaparken emeklerinin karşıllı̆ını maddi olarak almanın yanı sıra manevi olarak iş doyumu yaşamayı arzu etmektedirler. Özellikle dezavantajlı gruplarla çalışan söz konusu elemanların motivasyonlarının yüksek olması ve mesleki olarak doyum yaşaması hem ciddiyet hem de aidiyet duygularının artmasını sağlaması bakımından önemli bir unsurdur (Ceylan, Gül \& Öksüz 2016,45).Yapılan çalışma kapsamında "İşinizi yaparken mesleki doyum yaşıyor musunuz?" sorusuna katılımcılar şu şekilde cevap vermişlerdir:

G.K. 48. "İşim ile ilgili mesleki bir doyuma ulaşabiliyorum. Mesleki bazı tanımlama ve yeterlilik belirleme konusunda eksiklikler mevcut olsa da bunu bir şekilde tolere edip mesleki doyuma ulaşabiliyorum".

G.K. 3. "Çalıştı̆̆ım alana dair mevzuatların veya yönetmeliklerin sınırlılığ içerisinde kısmen mesleki doyum sağlayabiliyorum. Uyguladı̆̆ım 
çalışmalara engel olan ve beni klsitlayan prosedürler olmasaydl; topluma çok daha fazla müdahale edebileceğimi ve kalıcı çözümler sunabileceğimi, mesleki doyuma ulaşabileceğimi düşünüyorum”.

G.K. 37. "Bir psikolog olarak mesleki doyumu çok fazla yaşayamamaktayım. Hatta bahsettiğim nedenlerden 'işe yaramama' hissini yoğun yaşanmasına, bu da kisa sürede tükenmişlik hissedilmesine neden olduğunu düşünüyorum”.

G.K. 24. "Kadın hizmetlerinde çalı̧mak özen ve ilgi isteyen bir alandır. Şiddet gören ve travmatize olmuş kadınlar ile çalışmak bir psikoloğun aktif yer alması gereken bir alandır. Ancak, görev tanımlarının yeterli düzeyde yapılmamış olması ve psikoloğun yapabileceği iş ve görevlerin idareciler tarafindan yeterince bilinmemesi nedeniyle iş doyumu düşmektedir. Ayrica travmatize olmuş vakalarla çalışmak, uzmanlar için de travmatize edici olabilmekte, tükenmişliğe yol açabilmektedir"

G.K. 10. "Mesleki doyum alamadı̆̆ım, ıvır zıvır işlerle uğraştı̆̆ım zamanlar oldu, tükenmişlik hissettiğim, kurum değişikliği yapma isteğim oldu. Ancak şu an için iki senenin çabasıyla mesleki doyum almaya yeniden başladım. Bir revize sürecinden sonra kendimi bu alanda daha iyi hissediyorum. Yaptı̆̆ım işle ilgili şu an için evet Yaptı̆̆ım işten tatmin olduğumu hissediyorum diyebiliyorum".

Meslek elemanlarının işini severek ve gereken fedakârlıkla yapması ve bundan maddi doyumun yanı sıra manevi doyum sağlaması oldukça önemlidir. Bu doyumun hissedilmesiyle birlikte hem hizmet veren hem de hizmet alan tarafın daha verimli olacağı düşünülmektedir. Konuyla ilgili olarak yapılan çıkarımlar, çalışanların çok fazla prosedüre takıldığı, kendi alanıyla ilgili ça1ş̧madığı, çözüme yönelik noktalarda yer almak istediği noktalarında yoğunlaşmaktadır.

Genel bir değerlendirme yapıldığında, mesleki doyum ve yeterlilik konusunda birtakım sorunların olduğu görülmüştür. Uygulama ve içerik yönünde revize edilmesi gereken noktaların bulunduğu açıktır. Yine dezavantajlı gruplarla çalışan bu meslek grubunun tükenmişlik yaşamamas1 ve kendini yeterli ve yetebilen bir noktada nasıl hissettiği önemlidir. Kuşkusuz yeterlilik konusu öğrenme süreciyle hep devam eden bir süreçtir. Ancak daha fazla mesleki eğitim, vaka odaklı uygulama ve tecrübeyle donatılmış meslek elemanlarının kendini alana daha hâkim hissedeceği düşünülmektedir.

\section{Görüşülenlerin Görüş ve Önerileri}

Kadınların refahını artırmaya yönelik çalışan meslek elemanlarının mesleki yeterlilik ve iş doyumuna yönelik yapılan çalışmada alana yönelik çıkarımlarda bulunduktan sonra görüşülenlere "Verilen hizmet ve uygulamaların eksik kaldı̆g yönlerin olduğunu düşünüyor musunuz?" sorusu yöneltilmiştir. Konuyla ilgili verilen yanıtlar çeşitlilik göstermektedir. Üzerinde en çok durulan; yönetmelik ve uygulamalardaki eksik noktaların giderilmesi, gizliliğin sağlanması, kadına yönelik cinsiyetçi bakış açısının değiştirilmesi, kadının güçlendirilmesi ve kadının ekonomik bağımsızlığını kazanması için her bakımdan desteklenmesi konularıdır.

G.K. 24. "Şiddet mağduru kadınlara yönelik uygulamalar hakkinda bilgi alınması, söz konusu uygulamalara yönelik tamamlayıcı önerilerin alınması ve kadın refahına yönelik çalışan personele yönelik öneriler olmalı. Uygulamalardaki eksiklikler giderilmeli”. 
G.K. 59. "Kişilerin kendilerine düşen görevi tam anlamıyla yapmaması ve bürokrasinin yavaşlı̆̆ kriz anında ve sonrasındaki müdahale sürecinde aksamalar hatta can kaylplarina neden olmaktadır".

G.K. 34. "Kadınlara kurum içerisinde gerek idareciler gerekse diğer personeller tarafindan müracaatçı muamelesi yapılması, 'Kadın da şiddeti hak ediyor' bakış açısının var olması, kadınlara nesneleştirilmesi üzerine yaşanan konuşmalar ve tartışmalar kurum içerinde en çok rahatsız olduğum şeyler arasindadır”.

G.K. 33. “...Kadınlar konukevine yerleştirildikten sonra güçlendirici çalışmaların yetersiz olduğunu düşünüyorum. Genelleme tabii ki yapamam ama çalıştı̆̆ım süre boyunca ă̆ırlıklı olarak kafası karışık ve her an geri dönmeyi düşünen kadınlarla karşılaştım. Bunun en önemli sebebi de ekonomik bağımsızlı̆̆ının olmayışının verdiği güvensizlik bence. Kadın, eşi olmadan hayatını nasıl geçindireceği, çocuklarına nasıl bakacă̆ı konusunda endişeli oluyor bu durum da eşine geri dönmesine sebep oluyor. Bu yüzden kadınların bir iş sahibi olmalarına yönelik çalışmalar yapılabilir. Meslek edindirme kursları bu ihtiyacı tam olarak karşılayamıyor. Belki bu durumdaki kadınlara iş konusunda öncelik tanınabilir".

Uygulamalara yönelik olarak alınan çeşitli önerilerin yanı sıra eğitime yapılan vurgu dikkat çekicidir. Alanda çalışan meslek elemanlarının gerekli eğitimi almaları yönünde öneriler olmakla beraber, kolluk kuvvetlerinin de süreçte daha etkin ve konu hakkında bilgilendirilmiş olması yönündeki öneriler de mevcuttur. Her iki durumun da üzerinde hassasiyetle durulması önemlidir.

G.K. 45. "Ihtisaslaşmayı gerektiren bir alan olduğunu düşündüğümden bu alanda hizmet verecek olan meslek, yardımcı meslek ve destek elemanlarının gerekli eğitimleri aldıktan sonra hizmet sunumuna dahil olmaları ve bu döngüyü aynı şeklide uygulamaya devam ederek alana yeni personel sokulmalı diye düşünüyorum”.

G.K. 47. "Bu alanda çalışan kişilerin aile ile ilgili tam anlamıyla çok iyi bir eğitim almış olması gerekli. Kanunların yaptırım gücü daha etkili olmall. Kolluk kuvvetlerinin de tedbir kararlarında eksik yönleri var ve bu eksiklikleri tam anlamiyla bir eğitimden geçirilerek giderilmeli".

G.K. 59. "Meslek elemanlarının personeli düzenli olarak seminerler aracllığ ile eğitmesi ve ilk adımda ki müdahalenin önemini kavratması, il idari amirinin bu konuda tam desteğinin sağlanmaya çalışılması gerekli bence".

G.K. 7. "Danışmanlık yapan kişilere alanla ilgili uzmanlarca sürekli eğitimler verilmesi gerekli diye düşünüyorum”.

Konuyla ilgili eksik görülen noktalar saptandıktan sonra bu noktalara yönelik kişisel önerilerinin neler olduğu sorulmuştur. Bu noktada özellikle şiddet gören kadının konukevi ve sonraki süreçlerinde yaşanan durumlarla ilgili olarak öneriler mevcuttur. Koruma altına alınan kadının evinden uzaklaştırılması, buna karşın şiddet uygulayan eşin rahatça hayatına devam etmesi travma yaşamış kadının durumunu negatif yönde etkilemektedir. Bununla beraber ekonomik 
özgürlüğü olmayan kadınların hayatını gerekli standartlarda devam ettirebilmesi için destek verilmesi noktasında öneriler bulunmaktadır. Yine gizlilik konusunda gerekli hassasiyetin gösterilmesi mevcut öneriler arasındadır.

G.K. 27. “...Şiddet mağduru kadını alıp kadın konukevine yerleştirmekten öteye geçebildiğimizi düşünmüyorum. Şiddeti uygulayan evinde kalmaya devam eder, sokaklarda rahatça dolaşır ve bizler kadını korumak adı altında kadını bir eve kapatır, bazı hallerde de çocuklarından ayırıriz. İhtiyaç halinde de verilen az miktarda para ile yaşam kurması sağlanır. Fakat bu yardım oldukça yetersiz kalmaktadır. Bu yüzden şiddete uğrayan kadının uğradĭ̆ı şiddeti şikâyet edebilmesi ve şiddeti terk edebilmesi için ona bir güvence sunulmalıdır. Bu konuda sosyal politikalar yetersidir. Yaşadiğı sosyo-ekonomik çevre açısından eğitimini tamamlayamamış ve iş tecrübesi olmayan kadının ekonomik anlamda toparlanan dek gıda, kira ve çocuklarının ihtiyaçları doğrultusunda yardım yapılmalı ve istihdam imkânı sunulmalıdır"

G.K. 18. "Bürokratik engeller çok fazla, işler yavaşlıyor"

G.K. 24. “...Öncelikli olarak, şiddet mağduru ve güvenlik ihtiyacı olan kadınların evden uzaklaştırılmaları ve kadın konukevine yerleştirilmeleri onların yaşadıkları travmayı artıran bir şeydir. Evden ve ailelerinden uzaklaştırılmaları yaşadıkları travmaları artırıcı rol oynamaktadır. Kesinlikle yanlış bir politika olduğunu ve faillerin evden uzaklaştırılmaların gerekli olduğunu düşünüyorum. Ruh sağlliğl olumsuz etkilenen ve şiddet eğilimli kadınlar ile aynı ortamda bulunacak diğer kadınların risk altında olduğunu düşünüyorum. Kadın konukevlerinin resmiyette adres bilgileri gizli olsa da sosyal hayatta bu kurumların yer bilgilerinin erişebilir olduğunu ve ulaşım görevlileri, çevrede yaşayan insanlar, kurum çalışanlarının yakınları tarafindan bilindiğini düşünüyorum, gizliliğin ihlal edildiğini düşünüyorum. Belirttiğim eksiklikler ışı̆̆ında, kadın hizmetlerinin revize edilmesini, kurum personellerine süpervizyon imkânlarının săglanmasının, hassa ve can güvenliği tehlikesi içermesi nedeniyle üst düzey dikkat ve hassasiyet gösterilmesi gerektiğini, bu alanda yalnızca deneyimli personellerin müdahalede bulunmasını öneriyorum"

Vaka odaklı çalışan meslek elemanları yaşanan olayların süreçlerine birebir tanık olmaktadırlar. $\mathrm{Bu}$ yüzden birçok açıdan duygular, sevinç ve hüzün bir arada yaşanmaktadır. Çalışanlara bu noktada "unutamadıkları bir anılarının olup olmadı̆̆ı" sorusu yöneltilmiştir. Bu noktada meslek elemanlarını etkileyen anılardan bazıları şu şekilde paylaşılmıştır:

G.K. 62. "Bir annenin kızına son defa bakışını hatırlıyorum"

G.K. 28. "Bir kadının çalıştı̆̆ım kuruma müracaat etmesi ve yapılan yazışmalar, açılan davalar ile çocuğun başka bir ilden alınarak anneye teslim edilmesidir. Çocuk ve annenin o anki mutluluğu beni en çok etkileyen anlardan birisidir.

G.K. 4. "Davranışsal boyutta çok etkileyici bir durum olmadı çünkü bir müddet sonra mesleki açıdan bazı şeyler kanıksanıyor. Belki de kadınların yetişkin olmalarlyla alakalı bir durum. Beni en çok çocuklarla ilgili 


\section{konular etkiliyor diyebilirim".}

G.K. 27. "Yüzü gülen çocuklar ve madde bağımlıllğından kurtulan az sayıda müracaatçı unutamayacă̆ım mutlu anılar olarak kaldı”.

G.K. 49. "Bir çocuğun yardım çağrısı unutamayacă̆ım anlardan biri. Sonrasında çocuğu alıştığı ve sevdiği başka bir aile yanına yine koruyucu aile hizmeti kapsaminda yerleştirdik".

G.K. 38. "Ruhsal bozukluğu olan bir bayanın çocuğuyla birlikte günlerce sokaklarda yaşaması beni etkileyen olaylardan biridir".

Mülakat sırasında uzmanların bu anıları anlatırken duygulandıkları, kimilerinin ise büyük bir mutlulukla güzel anılarını paylaştıkları gözlemlenmiştir. Meslek elemanlarının sorunları çözme noktasında yer almasının hem vakalara hem de iş doyumu anlamında kendilerine büyük faydası dokunmaktadır. Bu döngüye vakanın ve meslek elemanlarının süreç içindeki durumlarını olumlu olarak destekleyen sosyal politika uygulamaları da eklendiğinde hali hazırdaki süreç daha etkili ve verimli hale gelecektir.

\section{Sonuç ve Öneriler}

Son y1llarda meydana gelen toplumsal değişim ve dönüşüm dezavantajlı gruplar üzerine çalışan meslek elemanlarının sayıca artmasına neden olmuştur. Nicelik olarak artış gösteren bu meslek elemanlarının çalıştıkları özel gruplar sebebiyle mesleki yeterliliklerinin ve iş doyumlarının da yüksek olması beklenmektedir. Bu düşünceden hareketle çalışmada kadının refahına yönelik çalışan meslek elemanlarının iş doyumu ve mesleki yeterlilikleri hakkındaki görüşleri ele alınmıştır. Çalışma kapsamında sosyolog, sosyal çalışmacı, psikolog, çocuk gelişimi uzmanı olarak görev yapan 65 meslek elemanı ile derinlemesine mülakat yapılmıştır. Araştırmaya katılım sağlayan meslek elemanları için genel bir profil çizilmek istenirse katılımcıların büyük oranda kadın, bekar, 20-30 yaş aralığında, il doğumlu ve lisans mezunu oldukları söylenebilir.

Çalışmada belirtildiği üzere Ko (2012), bireyin meslek seçiminin iş doyumu üzerinde önemli bir etkisi olduğunu savunmaktadır. Bu noktada mevcut örnekleme üniversitede okudukları bölümü seçme sebeplerinin ne olduğu sorulmuş ve kişilerin okudukları bölümü kendi ilgi ve istekleri doğrultusunda okumaya karar verdikleri görülmüştür. Katılımcılar aynı zamanda seçtikleri bölümün gelecek vaat eden alanlar arasında yer almasının tercihleri üzerinde etkili olduğunu belirtmişlerdir. Çalışmada katılımcıların mesleklerinden beklentilerinin ne olduğu ve bu beklentilerinin karşılanıp karşılanmadığı konusu üzerinde ayrıca durulmuştur. İlk etapta katılımcıların beklentilerini dezavantajlı görülen gruplara katk1 sağlamak, güçlü bir mesleki örgüt içerisinde çalışmak, okuduğu alana dair sahip olduğu bilgi ve ilgi bağlamında iş yapmak, güçlendirme çalışmaları yürütmek ve çözüm odaklı müdahalelerde bulunabilmek gibi faaliyetlerin oluşturduğu göze çarpmaktadır. Ne var ki bilerek ve isteyerek seçtikleri bölümlerde okuyan meslek elemanlarının mesleki anlamda beklentilerinin karşılanmadığı görülmüştür. Dahası lisans döneminde daha çok teoriye dayalı dersler alındığı ve bunun sonucunda uygulama noktasında yetersiz kalındığı yönündeki görüşler ağır basmaktadır. Bu noktadan hareketle üniversitede alınan teorik eğitimlerin yanı sıra alana yönelik uygulamalı eğitimler alınmasının bireylerin mesleki anlamda beklentilerinin karşılanması ve motivasyonlarının artması açısından oldukça önemli olduğu söylenebilir.

Ceylan ve arkadaşları (2016) hizmet içi eğitimlerin iş doyumunu etkileyen temel etmenler arasında yer aldığını ifade etmektedir. Özellikle toplum içerisinde bireylerin hemen her türlü sorunlarına çözüm aramaya çalışan meslek elemanlarının eğitimlerinin daha çok teoriye dayalı 
olması, bu kişilerin iş doyumunu etkilemekte ve çalıştıkları kurumlarda oryantasyon eğitimi almalarının önemini artırmaktadır. Ancak elde edilen veriler 1şı̆̆ında oryantasyon eğitimi alan çalışanlar katılımcıların yarısını oluşturmaktadır. Araştırma sonucunda elde edilen bulgulardan bir diğeri de meslek elemanlarının yine yarısından fazlasının kendini yetersiz hissetmeleridir. Katılımcılar bu duruma mesleki anlamda bir uzmanlaşma olmamasının ve mesleki sınırlarının kesin olarak çizilmemesinin sebep olduğunu belirtmektedirler. Douglas ve Philpot'un (1998) Amerika'da sosyal çalışma görevlileri üzerinden verdiği örnekler mevcut araştırma kapsamında verilen cevaplar birlikte değerlendirildiğinde gelişmiş ülkelerde sosyal çalışma görevlilerinin uzmanlaşması yönünde yapılan çalışmaların Türkiye'de yeterli seviyede olmadığı söylenebilir. $\mathrm{Bu}$ durumda da bireylerin mesleki doyumlarının düşük olması arasında bir ilişki olduğu düşünülebilir. Zira mesleki doyum sağlayıp sağlamadıklarına yönelik yöneltilen soruya katılımcıların çoğunluğu mesleki doyum sağlayamadığı yönünde görüş belirtmiştir.

Alanın içinde olmaları ve yaşanan sorunları bizzat dile getirmeleri bakımından kadın refahına yönelik çalışan meslek elemanlarının görüş ve önerileri oldukça önemlidir. Bu noktada katılımcılar yönetmelik ve uygulamalardaki eksik noktaların giderilmesi, gizliliğin sağlanması, kadına yönelik cinsiyetçi bakış açısının değiştirilmesi, kadının güçlendirilmesi ve kadının ekonomik bağımsızlığını kazanması için her bakımdan desteklenmesi konularının üzerinde durmuşlar ve bu eksikliklerin giderilmesi noktasında özellikle şiddet gören kadının konukevi ve sonraki süreçlerinde yaşanan durumlarla ilgili olarak önerilerde bulunmuşlardır. Kadınların refahını artırmaya yönelik çalışan meslek elemanlarının ilgili hizmetleri değerlendirmesi ve önerilerde bulunması mevcut politikalar ile hizmetlerin gözden geçirilmesi ve iyileştirilmesi konusunda büyük önem taşımaktadır. Ayrıca Türkiye'de kadın refahı alanında verilen hizmetlerin ve meslek elemanlarının alan deneyimlerinin incelenmesi uluslararası ölçekte karşılaştırma yapma imkanı da sağlamaktadır.

Kadının refahına yönelik yapılan çalışmalar kadının sosyal yapı içindeki yerinin güçlendirilmesi ve aynı zamanda toplumsal yapının güçlenmesi anlamına gelmektedir. Destek ve yardıma ihtiyaç duyan her kesim ve kişiye ulaşma ve topluma kazandırmanın sağlıklı toplum olma yönünde büyük önem taşıdığı düşünüldüğünde, bu alanda çalışan meslek elemanlarının önemi bir kez daha karşımıza çıkmaktadır. Bu anlamda; yapılan çalışma sadece kadın refahına yönelik çalışan meslek elemanlarına yönelik gerçekleştirilmiş olup, istenildiğinde diğer dezavantajlı gruplar ile çalışan personel ile daha geniş bir yelpazede gerçekleştirilmesi de önemli katkılar sağlayacaktır. Böylelikle alan çalışanlarına yönelik detaylı bir uygulama ve öneri haritası oluşturulabilme ihtimali doğmaktadır. Buradan hareketle çalışanların öncelikli problemlerinden başlanarak çözüme yönelik uygulamaların hayata geçirilmesi oldukça önemlidir.

\section{KAYNAKÇA}

Aziz A. (2014). Sosyal Bilimlerde Araştırma Yöntemleri ve Teknikleri. Ankara 2014.

Ceylan H., Gül N. \& Öksüz M. (2016). "Sosyal çalışmacılarda İş Doyumu ve Tükenmişliğe Etki Eden Faktörlerin Sosyal Hizmet Alanlarına Göre Karşılaştırmalı İncelenmesi”. Yalova Üniversitesi Sosyal Bilimler Dergisi 11/6 (2016) 43-69.

Cree E. V. (2003). “Introduction”. Ed. V. E. Cree, Becoming A Social Worker (2003) 1-9. London 2003.

Danış M. Z. \& Genç Y. (2011). "Kurumsal Bakım Elemanlarının Genel Özellikleri ve Yaşadıkları Sorunlar”. Yalova Sosyal Bilimler Dergisi 2 (2011) 170-183.

Dedeoğlu S. (2009). 'Eşitlik mi Ayrımcılık mı? Türkiye’de Sosyal Devlet, Cinsiyet Eşitliği Politikaları ve 
Kadın İstihdamı”. Çalı̧ma ve Toplum 2/21 (2009) 41-54.

Douglas A. \& Philopot T. (1998). Caring and Coping: A Guide to Social Services. London 1998.

Ertürk E. \& Keçecioğlu T. (2012). "Çalışanların İş Doyumları ile Mesleki Tükenmişlik Düzeyleri Arasındaki İlişkiler: Öğretmenler Üzerine Örnek Bir Uygulama”. Ege Akademik Bakış 1/12 (2012) 41-54.

Genç Y. \& Barış İ. (2015). "Sosyal Hizmetlerin Yeniden Yapılandırılmasında Yerinden Yönetimin İşlevselliği”. The Journal of Social Science Studies 32 (2015) 95-117.

Judge A. T. \& Larsen J. R. (2001). "Dispositional Affect and Job Satisfaction: A Review and Theoretical Extension”. Organizational Behaviorand Human DecisionProcesses 86/1 (2001) 67-98.

Gardulf A., Nilsson J., Florin J., Leksell J., Lepp M., Lindholm C., Nordström G., Theander K., WildeLarsson B., Carlsson M. \& Johansson E. (2016). "The Nurse Professional Competence (NPC) Scale: Self-reported Competence among Nursing Students on the Point of Graduation". Nurse Education Today 36 (2016) 165-171.

Garner G. (2008). Careers in Social and Rehabilitation Services. USA 2008.

Güler A. B. (2006). "Sosyal Devlet ve Yerelleşme”. Memleket Siyaset Yönetim 2 (2006) 29-43.

Katzell R. A. (1964). "Personal Values, Job Satisfaction, and Job Behavior". Ed. H. Borav, Man in a Work at Work (1964) 341-363. Boston.

Ko W. (2012). "The Relationships among Professional Competence, Job Satisfaction and Career Development Confidence for Chefs in Taiwan”. International Journal of Hospitality Management 31/3 (2012) 1004-1011.

Lam T., Zhang H. \& Baum T. (2001). "An Investigation of Employees' Job Satisfaction: The Case of Hotels In Hong Kong". Tourism Management 22/2 (2001) 157-165.

Lieblich A., Tuval-Mashiach R. \& Zilber T. (1998). Narrative Research, Reading, Analysis and Interpretation Applied Social Research Methods Series. California 1998.

Litchfield E. R., Oakland J. M. \& Anderson J. (2002). "Promoting and Evaluating Competence in On-Line Dietetics Education”. Journal of the American Dietetic Association 102/10 (2002) 1455-1458.

Kane T. M. (1992). "The Assessment of Professional Competence". Evaluation \& The Health Professions 15/2 (1992) 163-182.

Mansfield S. R. (1996). "Building Competency Models: Approaches for HR Professionals". Human Resource Management (1986-1998) 35/1 (1996) 7.

Mount J. D. \& Bartlett A. L. (2002). "Development of a Job Satisfaction Factor Model for the Lodging Industry". Journal of Human Resources in Hospitality \& Tourism 1 (2002) 17-39.

Pushpakumari M. D. (2008). "The Impact of Job Satisfaction on Job Performance: An Empirical Analysis". City Forum 9/1 (2008) 89-105.

Robbins P. S. \& Coulter M. (1996). Management. Upper Saddle River 1996.

Saari M. L. \& Judge A. T. (2004). "Employee Attitudes and Job Satisfaction". Human Resource Management 43/4 (2004) 395-407.

Sousa-Poza A. \& Sousa-Poza A. A. (2000). "Well-Being at Work: A Cross-National Analysis Of The Levels And Determinants Of Job Satisfaction”. The Journal of Socio-Economics 29/6 (2000) 517-538.

Selcik O. \& Güzel B. (2016). "Sosyal Hizmet Mesleğinin Çalışma Alanı Ve Sosyal Hizmet Uygulamasının Türkiye Ölçeğinde Değerlendirilmesi”. Uluslararası Sosyal Araştırmalar Dergisi 46/9 (2016) 462-469.

Topliceanu L., Bibire L. \& Nistor D. (2015). "Professional Competences of the Personnel Working on Quality Control and Food Safety in the Food Industry". Procedia-Social and Behavioral Sciences 180 (2015) 1030-1037.

Vleuten C. V. (1996). "The Assessment of Professional Competence: Developments, Research and Practical Implications". Advances in Health Sciences Education 1/1 (1996) 41-67. 